\title{
Linkage refinement localises Sorsby fundus dystrophy between markers D22S275 and D22S278
}

Cheryl Y Gregory, Sujeewa Wijesuriya, Kevin Evans, Marcelle Jay, Alan C Bird, Shomi S Bhattacharya

\begin{abstract}
Sorsby fundus dystrophy is an autosomal dominant disorder which both clinically and histopathologically bears striking similarities to age related macular degeneration, one of the leading causes of blindness in the developed world. Recent studies have suggested a genetic localisation of the disease to chromosome $22 \mathrm{q}$ in a large genetic interval of approximately $25 \mathrm{cM}$. Independent genetic linkage analysis in a six generation British pedigree confirms linkage to the chromosome $22 \mathrm{q}$ region. A maximum two point lod score of 7.09 with no recombination was obtained with marker D22S280. Haplotype data positioned the disease between loci D22S275 and D22S278, thus significantly reducing the region on chromosome $22 \mathrm{q}$ where the gene is located.
\end{abstract}

(f Med Genet 1995;32:240-241)
Department of Molecular Genetics, Institute of Ophthalmology, Bath Street, London ECIV 9EL, UK

C Y Gregory

$S$ Wijesuriya

S S Bhattacharya

Department of Clinical

Moorfields Eye

Hospital, London, UK

K Evans

M Jay

A C Bird

Correspondence to: Dr Gregory.

Received 28 October 1994 Revised version 28 November 1994
Ophthalmology, accepted for publication
Sorsby fundus dystrophy (SFD) was originally described as an autosomal dominant retinal dystrophy with complete penetrance in five British families. ${ }^{1}$ Affected subjects are symptomatic by the fourth decade of life, and loss of central vision occurs either through choroidal neovascularisation or by geographic atrophy. ${ }^{2}$ The disease is characterised by delayed choriocapillary filling on fluorescein angiography ${ }^{2}$ with later deposition of confluent subretinal lipid containing material at the level of Bruch's membrane. ${ }^{3}$ These characteristics have features in common with pathological changes seen in age related macular degeneration, ${ }^{4}$ the commonest cause of blindness in Westernised society. Thus, elucidation of the precise pathogenic mechanism in SFD may shed light on the pathogenesis of age related macular degeneration.

Recently linkage analysis in a Canadian SFD
Two point lod scores between disease and $22 q$ linked markers

\begin{tabular}{|c|c|c|c|c|c|c|c|c|c|}
\hline \multirow[t]{2}{*}{ Marker } & \multicolumn{7}{|c|}{ Recombination fraction } & \multirow[b]{2}{*}{$Z \max$} & \multirow[b]{2}{*}{$\theta$} \\
\hline & $0 \cdot 0$ & 0.01 & 0.05 & $0 \cdot 1$ & $0 \cdot 2$ & $0 \cdot 3$ & 0.4 & & \\
\hline $\begin{array}{l}\text { D22S315 } \\
\text { D22S275 } \\
\text { D22S273 } \\
\text { D22S280 } \\
\text { D22S281 } \\
\text { D22S278 } \\
\text { D22S274 }\end{array}$ & $\begin{array}{l}-\infty \\
-\infty \\
2 \cdot 80 \\
7 \cdot 09 \\
6 \cdot 19 \\
-\infty \\
-\infty\end{array}$ & $\begin{array}{r}-0.34 \\
2.94 \\
2.72 \\
6.97 \\
6.08 \\
-0.56 \\
-6.42\end{array}$ & $\begin{array}{r}1.46 \\
3.71 \\
2.41 \\
6.48 \\
5.62 \\
1.13 \\
-3.19\end{array}$ & $\begin{array}{r}1.96 \\
3.80 \\
2.03 \\
5.84 \\
5.03 \\
1.52 \\
-1.96\end{array}$ & $\begin{array}{r}1.90 \\
3.21 \\
1.28 \\
4.46 \\
3.77 \\
1.33 \\
-0.88\end{array}$ & $\begin{array}{r}1 \cdot 35 \\
2 \cdot 23 \\
0.65 \\
2.96 \\
2 \cdot 43 \\
0.75 \\
-0.42\end{array}$ & $\begin{array}{r}0.62 \\
1.06 \\
0.22 \\
1.36 \\
1.06 \\
0.18 \\
-0.22\end{array}$ & $\begin{array}{l}1 \cdot 96 \\
3.83 \\
2 \cdot 80 \\
7 \cdot 09 \\
6 \cdot 19 \\
1.52 \\
-2 \text { lod }\end{array}$ & $\begin{array}{c}0.10 \\
0.08 \\
0 \cdot 00 \\
0 \cdot 00 \\
0.00 \\
0 \cdot 10 \\
\mathrm{~d}(\theta=0.09)\end{array}$ \\
\hline
\end{tabular}

family of Irish origin has shown localisation of the disease to chromosome 22q13-qter in a $25 \mathrm{cM}$ region flanked by markers D22S275 and D22S274..$^{5}$ To determine if one of the original families described by Sorsby et $a l^{1}$ was linked to chromosome 22q, conventional linkage analysis was carried out.

\section{Patients and methods}

From a six generation pedigree, ${ }^{2} 25$ family members were studied including 11 affected subjects, 12 unaffected subjects, and two spouses (figure A). Subjects were only confirmed as unaffected if they were over 55 years of age, with normal fundal appearance on clinical examination and fluorescein angiography, and had normal vision. Informed consent explaining the nature of the study was obtained from each patient. Seven microsatellite markers $^{6}$ mapping to the chromosome 22q SFD region $^{5}$ were used to genotype subjects. Two point lod scores were determined using MLINK $^{7}$ and multipoint analysis was undertaken using LINKMAP. ${ }^{7}$

\section{Results}

LINKAGE ANALYSIS

Two point lod scores for markers mapping to chromosome $22 \mathrm{q}$ in the region previously identified as linked to SFD are presented in the table. A maximum two point lod score of $7.09(\theta=0.00)$ with marker D22S280 confirmed tight linkage in our family to the SFD locus on chromosome 22q13.1. In addition, two other markers, D22S273 and D22S281, also showed no recombination with the disease giving two point lod scores of $2 \cdot 80$ and $6 \cdot 19$, respectively.

MULTIPOINT LINKAGE ANALYSIS

A series of four three point analyses were performed with the linked markers to generate a multipoint map of the region and is presented as a single graph (figure B). Two markers and disease were used in each analysis to calculate the likelihood of the disease gene being located between these two markers. The data suggested that the SFD disease locus was most likely to be in the interval between D22S273 and D22S280 with a peak lod score of 8.51 , or between D22S280 and D22S281 with a peak lod score of $7 \cdot 82$. The two lod confidence interval suggested that the disease locus was 


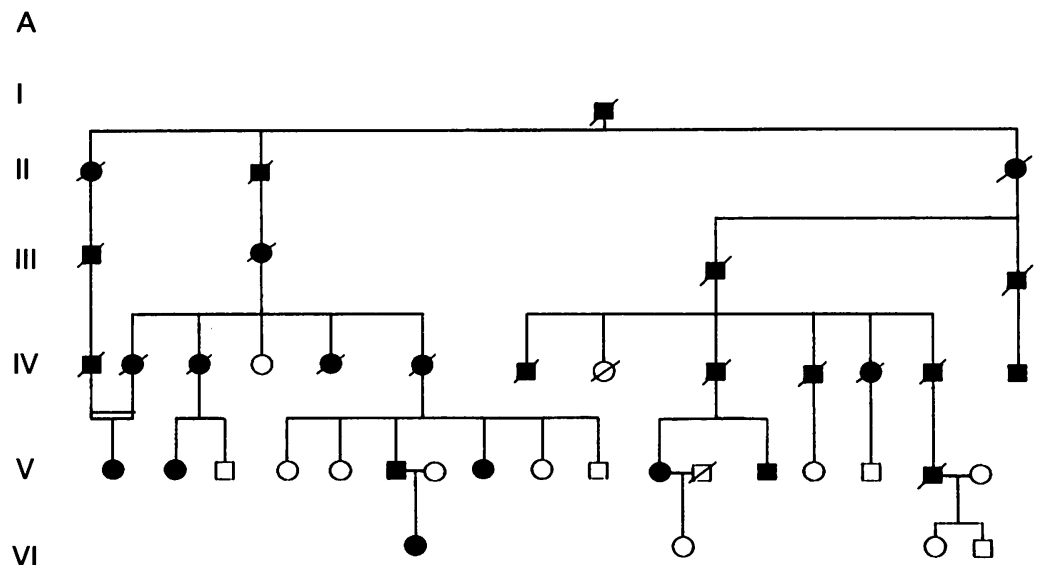

VI

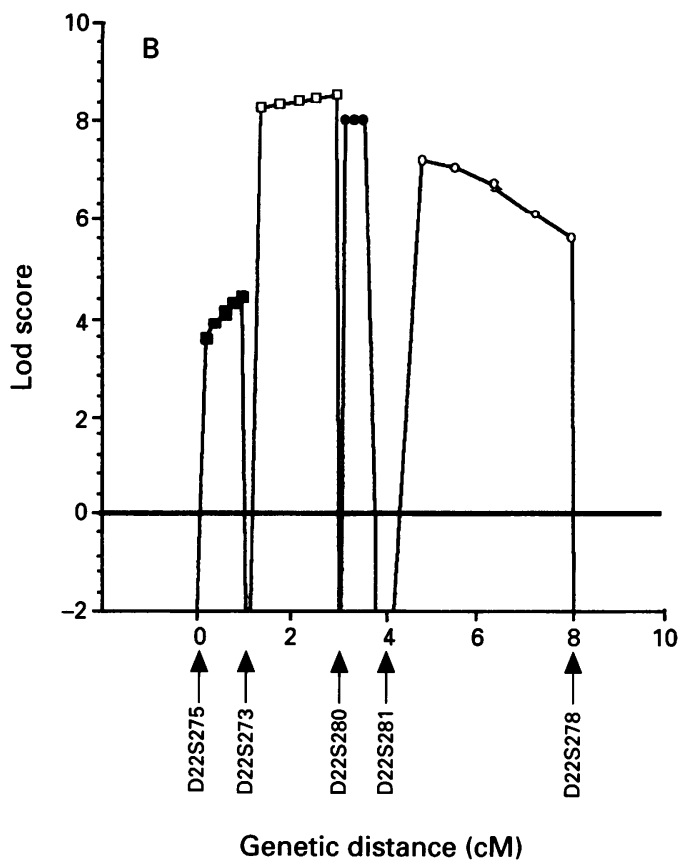

SFD linkage pedigree (A) and multipoint analyses (B) of the SFD region. (B) Each set of symbols represents a separate three point analysis. The genetic distance on the $x$ axis is arbitrarily set at zero for marker D22S275. The relative order of markers was obtained from published data. ${ }^{6}$ ation because of different mutations within the same gene, similar to that which has been seen in peripherin/RDS mutations. ${ }^{8}$ This hypothesis can be confirmed when the disease gene is identified.

The identification of critical recombinants within the pedigree has significantly improved the localisation of the disease locus to chromosome 22q13.1 within an $8 \mathrm{cM}$ interval in this family. There are two genes in the region which are possible candidates for the disease. The A1 adenosine receptor was localised to chromosome $22 \mathrm{q} 13^{9}$ and has been shown to be expressed in the retina. ${ }^{10}$ The second candidate is TIMP-3 which was recently mapped to chromosome 22q13." TIMP activity has been detected in interphotoreceptor matrix which lies between the neural retina and the retinal pigment epithelium. ${ }^{12}$ These two genes are currently being assessed for a role in the molecular aetiology of SFD. If they are not involved in the disease pathogenesis then generation of new markers in the region and positional cloning will be used to identify the disease causing gene for SFD.

The authors would like to thank The Wellcome Trust (CYG and $\mathrm{SW}$ ) and the Medical Research Council (KE) for supporting this research. We acknowledge the Human Genome Mapping Resources Centre for use of computing facilities and provision of oligonucleotide primers.

1 Sorsby A, Mason MEJ, Gardener N. A fundus dystrophy with unusual features. $\mathrm{Br} \mathcal{F}$ Ophthalmol 1949;33:67-97.

2 Polkinghorne PJ, Capon MR, Berninger T, Lyness AL Sehmi K, Bird AC. Sorsby's fundus dystrophy. A clinical study. Ophthalmology 1989;96:1763-8.

3 Capon MR, Marshall J, Krafft JI, Alexander RA, Hiscott PS, Bird AC. Sorsby's fundus dystrophy. A light and electron microscopic study. Ophthalmology 1989:96:176977.

4 Pauleikhoff D, Chen JC, Chisholm IH, Bird AC. Choroidal perfusion abnormality with related Bruch's membrane perfusion abnormality with related Bruch's

5 Weber BHF, Vogt G, Wolz W, et al. Sorsby's fundus dystrophy is genetically linked to chromosome 22q13-qter. trophy is genetically linked to

6 Gyapay G, Mortissette J, Vignal A, et al. The 1993-1994 Généthon human genetic linkage map. Nature Genet 1994; 7:246-335.

7 Lathrop GM, Lalouel JM, Julier C, Ott J. Strategies for multipoint linkage analysis in humans. Proc Natl Acad Sci USA 1984;81:3443-6.

8 Wells J, Wroblewski J, Keen J, et al. Mutations in the human retinal degeneration slow (RDS) gene can cause either retinitis pigmentosa or macular dystrophy. Nature Genet 1993;3:213-8.

9 Libert F, Passage E, Parmentier M, et al. Chromosomal mapping of $\mathrm{A} 1$ and $\mathrm{A} 2$ adenosine receptors, VIP receptor, and a new subtype of serotonin receptor. Genomics 1991; $11: 225-7$.

positioned in a $5 \mathrm{cM}$ interval according to published data. $^{6}$

\section{Discussion}

This study has confirmed linkage in our family to chromosome 22q13.1. The differences in clinical presentation of the disease that have been reported ${ }^{2}$ may represent phenotypic vari- 